\title{
Gambaran Perilaku Mahasiswa dalam Pencegahan Penularan Corona Virus 2019 Disease (Covid-19)
}

\author{
Ronasari Mahaji Putri ${ }^{1^{*}}$,Novita Dewi ${ }^{2}$, Neni Maemunah ${ }^{3}$ \\ ${ }^{1,2,3}$ Faculty of Health Sciences Tribhuwana Tunggadewi University, Jl. Telagawarna Tlagamas Malang \\ Email:* Correspondence: putrirona@gmail.com
}

Submitted : 13/08/2020

Accepted: 01/10/2020

Published: 06/03/2021

\begin{abstract}
The spread of covid-19 is increasingly out of control. Every individual has the potential to transmit covid to other humans. Various recommendations from the government for a healthy life have been made in an effort to break the chain of transmission, however it is not easy to change people's behavior into healthy behavior. This study aims to determine the description of student behavior in the prevention of covid transmission 19. This study is a descriptive study of 110 students residing in the FIKES dormitory of X University, taken using simple random sample technique. Variables are student behavior. The instrument used was a questionnaire distributed with the help of Google forms. Data analysis uses univariate test. The results showed that the majority of students namely 57 people (52.8\%) had a co-19 prevention behavior with a very bad category. It is recommended that researchers further provide health education to students about clean and healthy living behaviors related to co-19 prevention, given that co-19 transmission is increasingly widespread and has become an epidemic in the world
\end{abstract}

Keywords: behavior, covid 19, face mask, prevention, washing hands

\begin{abstract}
Abstrak
Penyebaran covid-19 semakin tidak terkendali. Setiap individu mempunyai potensi untuk menularkan covid kepada manusia yang lain. Berbagai anjuran dari pemerintah untuk hidup sehat telah dilakukan dalam upaya memutuskan rantai penularan, namun demikian tidak mudah untuk mengubah perilaku masyarakat menjadi berperilaku sehat. Penelitian ini bertujuan untuk mengetahui gambaran perilaku mahasiswa dalam pencegahan penularan covid 19. Penelitian ini merupakan penelitian deskriptif terhadap 110 mahasiswa yang bertempat tinggal di asrama FIKES Universitas X, diambil dengan menggunakan teknik simple random sample. Variabel adalah perilaku mahasiswa. Instrumen menggunakan kuesioner yang disebarkan dengan bantuan google form. Analisa data menggunakan uji univariat. Hasil penelitian menunjukkan bahwa sebagian besar mahasiswa yakni 57 orang ( $52,8 \%$ ) mempunyai perilaku pencegahan covid-19 dengan kategori sangat buruk. Direkomendasikan untuk peneliti selanjutnya memberikan pendidikan kesehatan kepada mahasiswa tentang perilaku hidup bersih dan sehat yang berkaitan dengan pencegahan covid-19, mengingat bahwa penularan covid-19 ini semakin meluas dan telah menjadi wabah di dunia.
\end{abstract}

Kata kunci : covid 19, perilaku, pencegahan, mencuci tangan, masker

\section{PENDAHULUAN}

Corona virus merupakan virus RNA yang berukuran partikel 120-160 nm. Virus ini pada utamanya hanya menginfeksi hewan, yakni pada kelelawar dan unta. Sebelum wabah COVID-19 melanda, terdapat 6 jenis coronavirus tertentu yang menginfeksi manusia, yaitu alphacoronavirus NL63, alphacoronavirus
229E, betacoronavirus OC43, Severe Acute Respiratory Illness Coronavirus (SARSCoV), betacoronavirus HKU1, dan Middle East Respiratory Syndrome Coronavirus (MERS-CoV) (Riedel S, Morse S, Mietzner T, Miller S. Jawetz, Melnick and Adelberg's, 2019). Masuknya COVID-19 dilaporkan pertamakali di Indonesia yakni tanggal 2 Maret 2020, baru sejumlah dua 
kasus(Organization, 2020). Sedangkan data pada tanggal 31 Maret 2020 menunjukkan peningkatan kasus yang terkonfirmasi berjumlah 1.528 kasus dan kematian sejumlah 136 kasus (Kementerian Kesehatan Republik Indonesia, 2020). Berdasarkan data WHO (2020) menunjukkan bahwa tingkat mortalitas COVID-19 di Indonesia sebesar 8,9\%, angka ini merupakan yang tertinggi di Asia Tenggara (World Health Organization, 2020b)((World Health Organization (WHO), 2020b). Dari data di atas menunjukkan bahwa penyebaran covid-19 ini menunjukkan peningkatan yang tajam, bahkan sudah menjadi wabah di Negara kita. Berbagai faktor resiko penularan covid-19 perlu menjadi perhatian masyarakat.

Penelitian (Cai, 2020);(Fang, Karakiulakis and Roth, 2020)menunjukkan bahwa berbagai faktor resiko dari infeksi SARS-CoV-2 yakni penyakit diabetes mellitus, penyakit komorbid hipertensi dan diabetes melitus, perokok aktif serta jenis kelamin laki-laki. Banyaknya penderita berjenis kelamin laki-laki diduga dihubungkan dengan tingginya aktivitas sebagai perokok aktif. Peningkatan ekspresi reseptor ACE2 meningkat pada orang dengan hipertensi, perokok, dan diabetes melitus. Upaya penemuan vaksin untuk memberantas Covid-19 sampai sekarang ini masih diupayakan. Peran masyarakat dalam mencegah penyebaran penularan covid-19 sangat dibutuhkan.

Berbagai upaya pencegahan penularan dimaksudkan dalam upaya memutuskan rantai penularan yakni melalui tindakan deteksi dini, isolasi serta melakukan proteksi dasar(Kemenkes RI, 2020). Menurut Han \& Yang, (2020) penyebaran SARS-CoV-2 saat ini mengalami kemajuan yakni dari manusia ke manusia dan hal ini menjadi sumber transmisi utama sehingga penyebaran lebih agresif. Transmisi SARS-CoV-2 dari pasien simptomatik melalui droplet saat pasien batuk atau bersin. Perilaku hidup bersih dan sehat (PHBS) masyarakat perlu dilakukan dalam upaya meningkatkan daya tahan tubuh. Berbagai perilaku masyarakat yang dianjurkan untuk dilakukan/gunakan antara lain adalah penggunaan Alat pelindung Diri ( APD ), dan melakukan hygiene cuci tangan dan semprot desinfektan.World Health Organization (WHO)mengungkapkan bahwa lomponen APD yakni ada masker, kacamata pelindung serta gaun nonsteril yang berlengan panjang, sarung tangan(WHO., 2020). Alat pelindung diri akan efektif dalam mencegah penularan covid-19 jika saja adanya kontrol teknik, lingkungan serta kontrol administratif dari pusat. Namun demikian World Health Organization (WHO) tidak menganjurkan penggunaan APD pada masyarakat umum yang tidak mempunyai gejala batuk, demam serta sesak nafas (World Health Organization, 2020a). Perilaku mencuci tangan juga harus menggunakan sabun dan tidak cukup hanya menggunakan air saja karena virus RNA memiliki selubung lipid bilayer yang hanya dapat dihilangkan dengan sentuhan sabun. Perilaku hidup bersih dan sehat setiap individu, sangat ditekankan untuk dilakukan. Namun demikian memang tidak mudah untuk mengkondisikan agar setiap individu mau dan dengan penuh kesadaran melakukan PHBS setidaknya untuk pencegahan diri dari penularan covid-19.

Hasil studi pendahuluan di asrama Fikes pada Bulan Maret 2020, diinformasikan bahwa ada awal penyebaran covid-19 dari 10 mahasiswa sebanyak 8 mahasiswa tidak menggunakan masker wajah saat berkomunikasi dengan teman, sebanyak 9 mahasiswa tidak mencuci tangan. Hasil wawancara dengan mahasiswa disampaikan bahwa mereka tidak mempunyai stok masker dan cenderung malas untuk sering mencuci tangan menggunakan sabun. Dari latar belakang di atas peneliti tertarik untuk mengetahui gambaran perilaku perilaku 
mahasiswa dalam pencegahan coronavirus 2019 disease(covid-19).Tujuan penelitian untuk mengetahui gambaran perilaku mahasiswa dalam pencegahan coronavirus 2019 disease(covid-19). Adanya dugaan dari peneliti bahwa masih banyak mahasiswa mempunyai perilaku sehat yang rendah, dalam upaya pencegahan diri terhadap virus covid-19. Penelitian ini dibatasi pada lingkup asrama Fikes Universitas $X$. Adapun target luaran yang ingin dicapai adalah publikasi artikel di jurnal terakreditasi.

\section{METODE PENELITIAN}

Penelitian ini merupakan penelitian deskriptif yang menyajikan gambaran secara keseluruhan perilaku mahasiswa dalam mencegah covid-19. Model penelitian yang digunakan adalah dengan menggambarkan / mempotret perilaku mahasiswa dalam pencegahan covid-19. Sampel sejumlah 110 mahasiswa yang tinggal di dalam asrama FIKes $\mathrm{X}$, yang didapatkan dengan menggunakan teknik simple random sample. Varibel dalam penelitian ini adalah perilaku mahasiswa dalam pencegahan covid 19. Instrumen yang digunakan dalam penelitian ini adalah kuesioner, disebarkan secara online yakni menggunakan google form. Analisa data dilakukan dengan bantuan SPSS versi 17 dengan uji univariat.

\section{HASIL DAN PEMBAHASAN \\ Tabel 1 Distribusi Frekuensi Berdasarkan Karakteristik Responden}

\begin{tabular}{|c|c|c|}
\hline Karakteristik & \multirow[t]{2}{*}{ Frekuensi } & \multirow[t]{2}{*}{$\%$} \\
\hline Semester & & \\
\hline 4 & 44 & 40,7 \\
\hline 6 & 60 & 55,6 \\
\hline 8 & 4 & 3.7 \\
\hline Usia (Tahun) & Frekuensi & $\%$ \\
\hline $17-19$ & 11 & 10,2 \\
\hline $20-22$ & 80 & 74,1 \\
\hline $23-25$ & 16 & 14,8 \\
\hline 25 keatas & 1 & 9 \\
\hline Jenis kelamin & Frekuensi & $\%$ \\
\hline Laki-laki & 36 & 33,3 \\
\hline Perempuan & 72 & 66,7 \\
\hline Tempat tinggal & Frekuensi & $\%$ \\
\hline Asrama & 68 & 73 \\
\hline Rumah kontrakan & 40 & 27 \\
\hline $\begin{array}{l}\quad \text { Dari Tabe } \\
\text { sebagian besar } \\
\text { menempuh di sen } \\
(40,7 \%) \text {, sebagi } \\
\text { berada dalam ren } \\
80 \text { orang }(74,1 \% \\
(66,7 \%) \text { respond } \\
\text { dan sebanyak } 68 \\
\text { asrama. }\end{array}$ & $\begin{array}{l}1 \text { diketahu } \\
\text { responden } \\
\text { ster } 6 \text { yakni } \\
\text { besar } 1 \\
\text { g } 20-22 \text { tah } \\
\text { sebanyak } \\
\text { adalah pe } \\
\text { ang }(73 \%)\end{array}$ & $\begin{array}{l}\text { bahwa } \\
\text { sedang } \\
\text { orang } \\
\text { ponden } \\
\text { yakni } \\
\text { orang } \\
\text { mpuan, } \\
\text { ggal di }\end{array}$ \\
\hline
\end{tabular}
asrama. 
Tabel 2. Distribusi Frekuensi sebagian besar (54,6\%) selalu ganti baju BerdasarkanPerilaku Responden Dalam setelah bepergian; sebagian besar Pencegahan Covid-19 responden $(38 \%)$ jarang melakuakan aktivitas fisik; sebagian besar responden

\begin{tabular}{|c|c|c|c|}
\hline $\mathbf{N}$ & Perilaku & \multirow[t]{2}{*}{ Frekuensi } & \multirow[t]{2}{*}{$\%$} \\
\hline \multirow[t]{4}{*}{1} & $\begin{array}{c}\text { Cuci tangan } \\
\text { menggunakan sabun }\end{array}$ & & \\
\hline & Jarang & 18 & 24,7 \\
\hline & Sering & 35 & 32,4 \\
\hline & Selalu & 55 & 55 \\
\hline \multirow[t]{4}{*}{2} & $\begin{array}{c}\text { Cuci tangan dengan } 6 \\
\text { langkah }\end{array}$ & Frekuensi & $\%$ \\
\hline & Jarang & 33 & 30,6 \\
\hline & Sering & 38 & 35,3 \\
\hline & Selalu & 37 & $\mathbf{3 4 , 3}$ \\
\hline \multirow[t]{5}{*}{$\mathbf{3}$} & $\begin{array}{c}\text { Membawapembersihtang } \\
\text { an dan menggunakannya } \\
\text { setiap saat }\end{array}$ & Frekuensi & $\%$ \\
\hline & Tidak pernah & 26 & $\mathbf{3 3 , 3}$ \\
\hline & Jarang & 40 & 66,7 \\
\hline & Sering & 20 & 18,5 \\
\hline & Selalu & 22 & 20,4 \\
\hline \multirow[t]{5}{*}{4} & Menggunakan masker & Frekuensi & $\%$ \\
\hline & Tidak pernah & 7 & 6,5 \\
\hline & Jarang & 35 & 32,4 \\
\hline & Sering & 32 & 29,6 \\
\hline & Selalu & 34 & $\mathbf{3 1 , 5}$ \\
\hline \multirow[t]{5}{*}{5} & Ganti baju setelah pergi & & \\
\hline & Tidak pernah & 4 & $\mathbf{3 , 7}$ \\
\hline & Jarang & 13 & 12 \\
\hline & Sering & 32 & 29,6 \\
\hline & Selalu & 59 & 54,6 \\
\hline \multirow[t]{5}{*}{6} & Aktivitas Fisik & & \\
\hline & Tidak pernah & 20 & 18,5 \\
\hline & Jarang & 41 & 38 \\
\hline & Sering & 32 & 29,6 \\
\hline & Selalu & 15 & 13,9 \\
\hline \multirow[t]{5}{*}{7} & Tidak berjabat tangan & & \\
\hline & Tidak pernah & 7 & 6,5 \\
\hline & Jarang & 51 & 47,2 \\
\hline & Sering & 28 & 25,9 \\
\hline & Selalu & 22 & 20,4 \\
\hline \multirow[t]{5}{*}{8} & Isolasidiri & & \\
\hline & Tidakpernah & 3 & 2,8 \\
\hline & Jarang & 14 & 13 \\
\hline & Sering & 43 & 39,8 \\
\hline & Selalu & 48 & $\mathbf{4 4 , 4}$ \\
\hline
\end{tabular}
$(47,2 \%)$ lebih sering berjabat tangan dengan teman; sebagian besar responden $(44,4)$ melakukan isolasi diri.

Tabel 3. Distribusi Frekuensi Berdasarkan Anjuran Asupan Gizi Responden Dalam Pencegahan Covid19

\begin{tabular}{|c|c|c|c|}
\hline No & Karakteristik & Frekuensi & $\%$ \\
\hline \multirow[t]{5}{*}{1} & $\begin{array}{c}\text { Konsumsi } \\
\text { makanan } \\
\text { bergizi }\end{array}$ & & \\
\hline & Tidak pernah & 1 & 9 \\
\hline & Jarang & 34 & 31,5 \\
\hline & Sering & 30 & 27,8 \\
\hline & Selalu & 43 & 39,8 \\
\hline \multirow[t]{5}{*}{2} & $\begin{array}{c}\text { Konsumsi } \\
\text { sayur dan } \\
\text { buah setiap } \\
\text { hari } \\
\end{array}$ & & \\
\hline & Tidak pernah & 2 & 1,9 \\
\hline & Jarang & 50 & 46,3 \\
\hline & Sering & 41 & 38 \\
\hline & Selalu & 15 & 13,9 \\
\hline \multirow[t]{5}{*}{3} & $\begin{array}{l}\text { Konsumsi air } \\
\text { putih cukup }\end{array}$ & & \\
\hline & Tidak pernah & 2 & 1,9 \\
\hline & Jarang & 24 & 22,2 \\
\hline & Sering & 34 & 31,5 \\
\hline & Selalu & 48 & 44,4 \\
\hline \multirow[t]{5}{*}{4} & $\begin{array}{c}\text { Konsumsi } \\
\text { vitamin }\end{array}$ & & \\
\hline & Tidakpernah & 14 & 13 \\
\hline & Jarang & 41 & 38 \\
\hline & Sering & 29 & 26,9 \\
\hline & Selalu & 24 & 22,2 \\
\hline
\end{tabular}

Dari Tabel 3 diketahui bahwa

Dari Tabel 2 diketahui bahwa sebagian besar $(55 \%)$ responden mencuci tangan menggunakan sabun; sebanyak $34,3 \%$ responden sering mencuci tangan dengan menggunakan 6 langkah; sebagian besar responden $(66,7 \%)$ jarang membawa dan menggunakan hand sanitizer ; sebagian besar responden $(32,4 \%)$ jarang menggunakan masker; sebagian besar 43 orang ( $39,8 \%)$ selalu mengkonsumsi makanan bergizi; sebanyak $46,3 \%$ responden jarang mengkonsumsi sayur dan buah ; sebagian besar responden $44,4 \%$ selalu mengkonsumsi air putih yang cukup; serta sebanyak $38 \%$ jarang mengkonsumsi vitamin. 
Tabel 4 Distribusi Frekuensi berdasarkan Kategori Perilaku Pencegahan Virus Covid19

\begin{tabular}{cccc}
\hline No & Kategori & Frekuensi & \% \\
\hline $\mathbf{1}$ & Baik & 6 & 5,6 \\
$\mathbf{2}$ & Buruk & 25 & 23,1 \\
$\mathbf{3}$ & Cukup & 20 & 18,5 \\
& Sangatburuk & 57 & 52,8 \\
\hline & Total & 108 & 100 \\
\hline
\end{tabular}

Tabel 4 menunjukkan bahwa sebagian besar mahasiswa yakni 57 orang ( 52,8\%) mempunyai perilaku pencegahan covid-19 dengan kategori sangat buruk. Sebagian besar mahasiswa mempunyai perilaku pencegahan covid19 dalam kategori sangat buruk. Data ini menunjukkan bahwa mayoritas responden belum melaksanakan protokol kesehatan sesuai yang dianjurkan oleh Pemerintah. Dengan tidak menjalankan protokol kesehatan ini, dimungkinkan responden beresiko dalam penularan covid-19. Ketidakpatuhan responden dalam melakukan pencegahan covid -19 ini tergambar dalam narasi di bawah ini.

Sebagian besar $(55 \%)$ responden mencuci tangan menggunakan sabun. Data ini menunjukkan kurang lebih separuh mahasiswa belum melaksanakan perilaku mencuci tangan ini. Padahal seperti yang diketahui bersama bahwa tangan merupakan salah satu bagian tubuh yang paling sering berinteraksi dengan dunia luar. Dari pernyataan ini tentunya menguatkan opini peneliti bahwa mencuci tangan ini sangat penting untuk dilakukan dalam pengendalian penyakit. Sebenarnya penanaman kebiasaan mencuci tangan ini sebaiknya dilakukan sejak dini, agar dengan pembiasaan sejak kecil akanmenjadi sebuah kebiasaan yang baik di saat dewasanya. Tentunya dengan menggunakan metoda yang sesuai untuk anak kecil agar mudah diingat dan dijalankan dengan hati yang riang. Seperti pada penelitian Hasanah,dkk (2018) yang mengungkapkan bahwa kemampuan mencuci tangan pada anak meningkat dengan menerapkan gerak dan lagu mencuci tangan. Luby et al.(2009) mengatakan bahwa mencuci tangan secara konsisten dengan menggunakan sabun mengurangi penularan diare dan pernafasan. Cuci tangan pakai sabun (CTPS) mampu menurukan diare $31 \%$ dan menurunkan sebanyak $21 \%$ penyakit infeksi saluran nafas atas (ISPA). Sependapat juga peneliti lain bahwa kebiasaaan CTPS mencegah diare hingga $50 \%$, dan juga ISPA $45 \%$; juga menemukan adanya hubungan antara cuci tangan dengan insinden diare(Habit et al., 2020). Burton et al., (2011)menguatkan penelitian sebelumnya bahwa CTPS lebih efektif dalam mematikan kuman dibandingkan dengan hanya mencuci tangan pakai air tanpa sabun.

Sebanyak 38 ,orang $\quad(35,3 \%)$ responden sering mencuci tangan dengan menggunakan 6 langkah. Dari data tersebut dapat disampaikan bahwa sebagian kecil saja yang masih mencuci tangan menggunakan 6 langkah dan sebagian besar mahasiswa masih tidak menerapkan 6 tahapan langkah mencuci tangan. Mencuci tangan menggunakan 6 tahapan ini sangat penting dan sebaiknya dilakukan.Ibrahim, I., Canini L, Andreoletti L, Ferrari P, D'Angelo R, Blanchon T, Lemaitre M, (2020) mengungkapkan bahwa mencuci tangan pakai sabun sebagai perilaku sepele yang memberikan sumbangan besar dalam mencegah penularan covid-19. Perilaku sepele ini tetap menjadi sebuah perilaku yang sulit untuk dilakukan jika tidak dipaksa dan dibiasakan sejak kecil. Dibutuhkan penanaman kebiasaan sejak kecil agar terwujud kebiasaan di masa dewasanya. Penelitian Suprapto, R.,dkk (2020) menemukan bahwa pembiasaan mencuci tangan dengan menggunakan 6 langkah (sesuai dengan anjuran WHO) akan dapat berhasil dengan bantuan ceramah, menggunakan pembelajaran audiovisual serta melakukan praktek langsung dengan 
menggunakan air mengalir. Dan untuk menumbuhkan pembiasaan mencuci tangan dengan 6 langkah ini dibutuhkan motivasi yang kuat(Habit et al., 2020). Novitaria,DR,dkk.(2018) ditemukan adanya hubungan antara motivasi dengan pelaksanaan cuci tangan. Adanya keterbatasan dalam ketersediaan air mengalir dan sabun dalam aktivitas di luar rumah, menyebabkan meningkatnya penggunaan handsanitizer untuk membantu membersihkan tangan. Sebagian besar mahasiswa tidak membawa hand sanitizer. Hal ini dikarenakan mahalnya biaya produksi dari hand sanitizer. Sesuai dengan Asfar and Yasser, 2018)yang mengungkapkan mahalnya harga hand sanitizer yang sangat tinggi saat ini serta kelangkaan akan bahan baku utama dan dibutuhkan sebuah inovasi yakni mengkombinasikan bahan alam dan bahan kimia.

Sebagian besar responden jarang menggunakan masker di masa pandemi covid-19. Perilaku responden ini menunjukkan salah satu perilaku yang buruk. Masker sebagai salah satu alat yang digunakan sebagai pengaman pribadi, berfungsi mencegah penularan langsung virus covid-19, yang ditularkan melalui percikan ludah penderita. Menurut (Coronavirus et al., 2020)(Chan et al., 2020)(Li Q, Guan X, Wu P, Wang X, Zhou L, Tong Y, 2020)(Huang et al., 2020)(Burke et al., 2020) menyampaikan bahwa percikan (droplet) penderita dan juga kontak secara langsung dengan jarak kurang dari 1 meter sebagai jalan penyebaran virus COVID-19. Pada saat penderita mengalami gangguan nafas yakni batuk, ataupun bersin maka akan terjadi percikan penderita ke orang normal sehingga agen akan terinfeksi melalui titiktitik seperti mulut, hidung, atau konjungtiva (mata). Penggunaan masker sebagai bagian upaya komprehensif dalam mencegah dan mengendalikan serta membatasi penyebaran penyakit-penyakit dari virus saluran pernapasan tertentu, termasuk COVID-19.

Masker digunakan untuk melindungi orang yang sehat (sebagai pelindung diri sendiri saat kontak dengan orang terinfeksi) atau sebagai pencegah untuk dapat mengendalikan sumber agar tidak menularkan lebih lanjut (orang yang terinfeksi). Namun demikian, penggunaan masker harus diiringi dengan perilaku pencegahan yang lain, agar efektif dalam mencegah penularan virus covid-19. (Coronavirus et al., 2020)(Chan et al., 2020)(Li Q, Guan X, Wu P, Wang X, Zhou L, Tong Y, 2020)(Huang et al., 2020)(Burke et al., 2020) However, the use of masks must be accompanied by other preventative behaviors, to be effective in preventing transmission of the covid-19 virus. Upaya pencegahan yang lain adalah kepatuhan dalam menjaga kebersihan tangan melalui cuci tangan menggunakan sabun, penjagaan jarak fisik, serta langkahlangkah pencegahan, pengendalian infeksi (PPI) lainnya sangat penting dalam mencegah penularan COVID-19 dari orang ke orang (World Health Organization (WHO), 2020a).

Penelitian sebelumnya yakni mengenai penyakit influenza, influenza-like illness, serta coronavirus manusia (selain COVID-19) membuktikan bahwa penggunaan masker medis mencegah penyebaran droplet infeksi dari orang terinfeksi dan simtomatik (pengendalian sumber) kepada orang lain serta kontaminasi lingkungan akibat dropletdroplet ini (Ibrahim, I., Canini L, Andreoletti L, Ferrari P, D'Angelo R, Blanchon T, Lemaitre M, 2020); (Macintyre et al., 2016). Berbagai upaya preventif agar terhindar dari penularan covid-19 juga dianjurkan oleh pemerintah yakni seperti segera ganti baju setelah bepergian dari luar, tidak melakukan jabattangan dengan teman, melakukan aktivitas fisik yang kontinyu agar daya 
tahan tubuh meningkat dan juga melakukan isolasi diri.

Hasil temuan peneliti bahwa sebagian besar responden sudah ganti baju setelah bepergian. Walaupun secara ilmiah, untuk penelitian terkait menempelnya mikroorganisme atau virus covid-19 belum ada namun upaya preventif ini lebih baik untuk dilakukan. Menurut Kepala Pusat Penelitian Poltekkes Jakarta I, diinformasikan bahwa pakaian bukan sebagai media penularan virus covid, namun droplet yang jatuh pada saat ada kontak dengan penderita dimungkinkan bisa menempel dimana saja terutama pakaian (Kemenkes, 2020)

Sebagian besar responden jarang melakukan aktivitas fisik( olahraga) di masa covid-19. Data ini menunjukkan bahwa responden relative kurang dalam menggerakkan tubuh yang mengeluarkan keringat tubuh. Aktivitas fisik sebenarnya memberikan banyak manfaat bagi mahasiswa, yakni meningkatkan kesehatan, kebugaran dan juga memperpanjang usia serta lainnya. Namun demikian tidak semua mahasiswa menjalankan aktivitas fisik sesuai dengan yang seharusnya. Hasil temuan ini sesuai dengan Penelitian(Farradika et al., 2019) yang menemukan sebanyak $47,8 \%$ mahasiswa mempunyai aktivitas fisik yang rendah. Hasil penelitian ini berbeda dengan penelitian (Egi, Prastiwi and Putri, 2017) yang menemukan bahwa sebanyak $70 \%$ remaja di SMK Kertha Wisata Tlogomas Lowokwaru Malang mempunyai aktivitas fisik yang baik.. menyampaikan bahwa aktivitas fisik merupakan suatu gerakan otot tubuh beserta system penunjangnya, yang dilakukan denegan mengeluarkan energy. Energi yang keluar dapat tampak dari pengeluaran keringat. Aktivitas fisik yang kurang akan menyebabkan munculnya penyakit kronis, dan diperkirakan sebagai salah satu penyebab tertinggi keempat pada kematian global kematian. Literatur lain mengungkapkan bahwa jenis latihan fisik yang dimaksud ada 2 jenis yakni aerobik exercise (seperti lari, sepeda, dan jalan cepat) dan jenis latihan anaerobik (stretching, yoga dan juga yoga(Of et al., no date). (Guilbert, 2003);(Miller D, Taler V, Davidson PSR, 2012)menyatakan bahwa melakukan aktivitas fisik mempunyai banyak manfaat yakni diantaranya menurunkan risiko stroke dan penyakit jantung coroner, diabetes dan hipertensi, kanker payudara dan kolon , dan juga depresi(Guilbert, 2003);(Miller D, Taler V, Davidson PSR, 2012).Dari narasi di atas, membuktikan bahwa melakukan aktivitas fisik ini perlu dilakukan untuk hidup sehat.

Perilaku sebagian besar responden lebih sering berjabat tangan dengan teman. Perilaku berjabat tangan sebenarnya merupakan perilaku yang baik karena menunjukkan keakraban antar seseorang. Namun demikian dengan muncul dan merebaknya virus covid-19, perilaku ini dianggap tidak baik karena memudahkan penularan virus melalui sentuhan tangan. Penelitian ilmiah tentang bahaya perilaku jabat tangan belum dilakukan, namun demikian ada anjuran untuk lebih baik dihindari. Dalam sebuah majalah menunjukkan sebuah Eksperimen yang dilakukan oleh Dr. Mark Slansky seorang professor pediatric di Sekolah Kedokteran David Geffen, UCLA yang melakukan penelitian sebelum merebaknya virus covid-19, menemukan bahwa terjadi penurunan jumlah orang yang terinfeksi virus dan bakteri(Health, Maret 2020)

\begin{tabular}{lll}
\multicolumn{2}{c}{ Sebagian besar } & responden \\
melakukan isolasi diri. & Data ini \\
menunjukkan bahwa & mayoritas
\end{tabular} mahasiswa sudah melakukan anjuran pemerintah dalam membatasi pergaulan selama masa covid-19. Menurut Kominfo (2020) yang disebut isolasi diri merupakan suatu tindakan dengan tinggal dan juga melakukan aktivitas di rumah 
selama masa 14 hari, menghubungi petugas kesehatan melalui via telephone dalam upaya menghindari kontak langsung dengan pihak lain, melakukan pemisahan diri (dengan menggunakan ruangan sendiri dan juga menghindari dalam menggunakan barang secara bersama-sama). Selalu memperhatikan sampah yang dibuang secara terpisah dengan sampah yang lain, dengan kondisi tertutup, serta jika melakukan pesan tanpa pertemuan ( tidak bertemu langsung dengan pengantar barang/makanan) .

Berdasarkan asupan yang dianjurkan pemerintah dalam upaya meningkatkan kesehatan tubuh, didapatkan hasil bahwa hampir separuh tidak selalu mengkonsumsi makanan bergizi, jarang mengkonsumsi buah, kurang mengkonsumsi air putih, dan sebagian kecil tidak mengkonsumsi vitamin. Data ini menunjukkan bahwa pemenuhan gizi mahasiswa kurang baik. Pemenuhan gizi yang kurang baik dalam jangka watu yang lama akan berpengaruh terhadap status imun mahasiswa. Di masa pandemic covid-19 ini, mahasiswa seharusnya mengkonsumsi makanan yang bergizi dan benar-benar sadar dengan mengikuti anjuran pemerintah termasuk dalam hal pemenuhan asupan gizi. Pola makan yang tidak baik juga berpengaruh terhadap imun.

Menurut Krenitsky J (2006) bahwa pola makan yang tidak baik akan menyebabkan seseorang mengalami defisiensi zat gizi yakni seperti vitamin, vitamin A, protein yang sebenarnya zat gizi ini sangat penting dan berperan dalam fungsi imunitas.Zat ini dikenal dengan imunonutrisi. Hasil penelitian ini juga membuktikan bahwa imunonutrisi berpengaruh dalam imunologik dan penurunan inflamasi. Selain dengan pola makan yang baik berdampak pada defisiensi zat gizi, juga akan memberikan dampak penyakit sebagai contoh gastritis.
Gastritis ini seringkali dialami oleh mahasiswa. Penelitian Sari, Putri and Agustin, 2010)membuktikan bahwa ada hubungan antara pola makan dengan timbulnya gastritis. Mengubah perilaku mahasiswa untuk lebih peduli terhadap kesehatan dirinya khususnya dalam bidang asupan makan, tidak mudah. Dibutuhkan secara kontinyu pemberian pendidikan kesehatan oleh seseorang yang dianggap "penting" oleh mahasiswa. Pendidikan kesehatan disini dalam upaya meningkatkan pengetahuan mahasiswa agar mempunyai sikap yang positif, dan berdampak pada perubahan perilaku. Sesuai dengan penelitian (Sari, Putri and Agustin, 2017) bahwa pendidikan kesehatan mampu meningkatkan skor pengetahuan tentang gizi.(Sari, Putri and Agustin, 2010).

Kurangnya konsumsi air putih pada remaja dari hasil penelitian ini sesuai dengan hasil temuan(Bakri, 2019)yang menemukan bahwa sebanyak 70,3\% remaja mengalami ketidakcukupan dalam konsumsi air putih. Air putih merupakan salah satu unsur yang dibutuhkan tubuh untuk hidup sehat. Air berfungsi sebagai zat faislitator, pelumas, pengangkut, katalisator, serta pengatur suhu tubuh. Tubuh mengandung $80 \%$ air, hal ini menjadi alasan kurangnya cairan pada tubuh akan menyebabkan terjadinya kematian pada seseorang. Secara fakta bahwa tingkat kesadaran seseorang untuk mengkonsumsi air utih sesuai anjuran , masih belum sesuai harapan. Peningkatan atvitas fisik di saat remaja menyebabkan tubuh juga membutuhkan asupan air yang lebih banyak.(Bakri, 2019). Adanya rekomendasi dari Institute of Medicine bahwa untuk laki-laki pemenuhan air sebanyak 3 liter (13 gelas), sedangkan untuk dan perempuan 2,2 liter (9 gelas) dari total minuman dalam sehari, dalam upaya mengindarkan dehidrasi serta dijauhkannya dari gangguan ginjal (Hastuti YD, Nasution E, 2015). Berbagai dampak penyakit akan di alami oleh mahasiswa jika kekurangan 
cairan, yakni rematik, sakit pinggang, rematik, , nyeri tulang leher, tekanan darah tinggi, tukak saluran pencernaan, kolesterol tinggi, obesitas, , stroke, kencing manis, ,batu ginjal, danjuga sembelit (Metta, 2011).Jika dikaitkan dengan wabah covid19 ini, setiap orang diupayakan agar dapat tetap menjaga dan mempertahankan kesehatan agar tidak mudah mengalami penularan virus covid-19, yang cenderung menyerang pada kelompok beresiko dan mempunyai daya tahan tubuh yang lemah.

\section{SIMPULAN}

Penelitian ini menyimpulkan bahwa sebagian besar mahasiswa mempunyai perilaku pencegahan covid-19 dengan kategori yang sangat buruk.

\section{SARAN}

Direkomendasikan untuk peneliti selanjutnya memberikan pendidikan kesehatan pada mahasiswa tentang perilaku hidup bersih dan sehat yang berkaitan dengan pencegahan covid-19.Hal ini sangat penting untuk dilakukan mengingat covid19 ini menyebar dengan sangat cepat dan sudah menjadi wabah di dunia.

\section{UCAPAN TERIMAKASIH}

Diucapkan terimakasih kepada Rektor Universitas Tribhuwana Tunggadewi yang telah memberikan support yang besar dalam publikasi artikel jurnal.

\section{DAFTAR PUSTAKA}

Alfi Nur Hasanah, Joko Wiyono, R. M. P. (2018)

'PENINGKATAN

KEMAMPUAN CUCI TANGAN DENGAN BENAR MELALUI GERAK DAN LAGU CUCI TANGAN PADA ANAK USIA PRASEKOLAH (4-6 TAHUN) DI TK AL-ISTIQOMAH

KELURAHAN TLOGOMAS KECAMATAN LOWOKWARU KOTA MALANG', Nursing News :
Jurnal Ilmiah Keperawatan, 3(2). Available at: https://publikasi.unitri.ac.id/index.p hp/fikes/article/view/938.

Asfar, A. M. I. A. and Yasser, M. (2018) 'Analisis Kualitatif Fitikomia Kandungan Flavonoid Ekstrak Kayu Sepang (Caesalpinia Sappan L.) Dari Ekstraksi Metode Ultrasonic Assisted Solvent Extraction', Jurnal Chemica, 19(2), pp. 15-25. doi: 10.13140/RG.2.2.34913.66400.

Bakri, S. (2019) 'Status gizi, pengetahuan dan kecukupan konsumsi air pada siswa SMA Negeri 12 Kota Banda Aceh', AcTion: Aceh Nutrition Journal, 4(1), p. 22. doi: 10.30867/action.v4i1.145.

Burke, R. M. et al. (2020) 'Active Monitoring of Persons Exposed to Patients with Confirmed COVID-19 - United States, January-February 2020', MMWR. Morbidity and mortality weekly report, 69(9), pp. 245-246. doi: 10.15585/mmwr.mm6909e1.

Burton, M. et al. (2011) 'The effect of handwashing with water or soap on bacterial contamination of hands', International Journal of Environmental Research and Public Health, 8(1), pp. 97-104. doi: 10.3390/ijerph8010097.

Cai, H. (2020) 'Sex difference and smoking predisposition in patients with COVID-19', The Lancet Respiratory Medicine. Elsevier Ltd, 8(4), p. e20. doi: 10.1016/S22132600(20)30117-X.

Chan, J. F. W. et al. (2020) 'A familial cluster of pneumonia associated with the 2019 novel coronavirus indicating person-to-person transmission: a study of a family cluster', The Lancet. Elsevier Ltd, 395(10223), pp. 514-523. doi: 10.1016/S0140-6736(20)30154-9.

Coronavirus, S. et al. (2020) 'Community 
Transmission of Severe Acute Respiratory', 26(6).

Egi, E., Prastiwi, S. and Putri, R. M. (2017) 'Hubungan Gangguan Tidur Dengan Tingkat Kesegaran Jasmani Remaja Putri Di Smk Kertha Wisata Kelurahan Tlogomas Kecamatan Lowokwaru Malang', Nursing News: Jurnal Ilmiah Mahasiswa Keperawatan, 2(1), pp. 292-303. Available at: https://publikasi.unitri.ac.id/index.p hp/fikes/article/view/171/205.

Fang, L., Karakiulakis, G. and Roth, M. (2020) 'Are patients with hypertension and diabetes mellitus at increased risk for COVID-19 infection?', The Lancet Respiratory Medicine. doi: 10.1016/S22132600(20)30116-8.

Farradika, Y. et al. (2019) 'Perilaku Aktivitas Fisik dan Determinannya pada Mahasiswa Fakultas Ilmu Ilmu Kesehatan Universitas Muhammadiyah Prof . Dr . Hamka The Behavior of Physical Activity and Determinants of Student at Faculty Health Science, University of Muhammadiyah', Arkesmas, 4(1), pp. 134-142.

Guilbert, J. J. (2003) 'The world health report 2002 - Reducing risks, promoting healthy life [2]', Education for Health, 16(2), p. 230. doi:

10.1080/1357628031000116808.

Habit, G. et al. (2020) 'Pembiasaan Cuci Tangan yang Baik dan Benar pada Siswa Taman Kanak-Kanak ( TK ) di Semarang', 2(2), pp. 139-145.

Han, Y. and Yang, H. (2020) 'The transmission and diagnosis of 2019 novel coronavirus infection disease (COVID-19): A Chinese perspective', Journal of Medical Virology. doi: 10.1002/jmv.25749.

Hastuti YD, Nasution E, A. E. (2015) 'Perilaku Konsumsi Air Minum pada Siswa/Siswi SMA Negeri 3 Medan tahun 2014', Gizi, Kesehatan Reproduksi dan Epidemiologi., 1(3).

Health (no date) 'hindari-jabat-tanganuntuk-cegah-penyebaran-viruscorona'.

Huang, C. et al. (2020) 'Clinical feature of patients infected with 2019 novel coronavirus in Wuhan, China', pp. 497-506. doi: 10.1016/S01406736(20)30183-5.

Ibrahim, I., Canini L, Andreoletti L, Ferrari $\mathrm{P}$, D'Angelo R, Blanchon $\mathrm{T}$, Lemaitre M, et al. (2020) 'Surgical mask to prevent influenza transmission in households: a cluster randomized trial', PLoS One, 5(11), p. e13998. Available at: https://doi.org/10.1371/journal.pone. 0013998.

Kemenkes (2020) 'Apakah pakaian Bisa Jadi Penularan Corona? .' Available at:

https://www.poltekkesjakarta1.ac.id/ read-gk-lrd-apakah-pakaian-bisajadi-media-penularan-corona--cekkata-dokter.

Kemenkes RI (2020) 'Pedoman Kesiapsiagaan Menghadapi Coronavirus Disease (COVID-19)', Direkorat Jenderal Pencegahan dan Pengendalian Penyakit.

Kementerian Kesehatan Republik Indonesia (2020) Infeksi Emerging: Media Informasi Terkini Penyakit Infeksi Emerging, Kemenkes RI. doi: $10.1155 / 2010 / 706872$.

Li Q, Guan X, Wu P, Wang X, Zhou L, Tong Y, et al (2020) 'Early Transmission Dynamics in Wuhan, China, of Novel CoronavirusInfected Pneumoni', Engl J Med, 38(13), pp. 1199-207.

Luby, S. P. et al. (2009) 'Difficulties in Maintaining Improved Handwashing Behavior, Karachi , Pakistan', 81(1), pp. 140-145.

Macintyre, C. R. et al. (2016) 'Cluster 
randomised controlled trial to examine medical mask use as source control for people with respiratory illness'. doi: 10.1136/bmjopen2016-012330.

Metta (2011) Sehat Dengan Air Putih Cara Sehat Alami. Surabaya: Stomata.

Miller D, Taler V, Davidson PSR, M. C. (2012) 'Review: measuring the impact of exercise on cognitive aging: methodological issues.', Neurobiol of aging, 33(622). Available at: http://www.elsevier.com/locale/neua ging.

Of, I. et al. (no date) 'a GUIDE For APPROACHES TO INCREASING',

Organization, W. H. (2020) Situation Report-42 [Internet].

Riedel S, Morse S, Mietzner T, Miller S. Jawetz, Melnick, \& and Adelberg's (2019) Medical Microbiology. 28th ed., Hill Education/Medical. doi: 10.20961/jiptek.v7i2.12722.

Sari, R., Putri, M. and Agustin, H. (2010) 'Hubungan pola makan dengan timbulnya gastritis pada pasien di universitas muhammadiyah malang', pp. 156-164.

WHO. (2020) Infection prevention and control during health care when COVID-19 is suspected: interim guidance, January 2020, Who. Geneva. Available at: url: https://tinyurl.com/r7w9key

[accessed 2020-05-29].

World Health Organization (2020a) Advice on the use of masks in the community, during home care and in healthcare settings in the context of the novel coronavirus (2019nCoV) outbreak, Who.

World Health Organization (2020b) 'Coronavirus disease 2019 (COVID19) Situation Report - 40', $\mathrm{WHO}$ Bulletin. doi: 10.1001/jama.2020.2633.

World Health Organization (WHO) (2020a) 'Anjuran mengenai penggunaan masker dalam konteks COVID -19 https://www.who.int/docs/defaultsource/searo/indonesia/covid19/anju ran-mengenai-penggunaan-maskerdalam-konteks-covid-19-june20.pdf?sfvrsn=d1327a85_2'. Available at: https://www.who.int/docs/defaultsource/searo/indonesia/covid19/anju ran-mengenai-penggunaan-maskerdalam-konteks-covid-19-june20.pdf?sfvrsn=d1327a85_2.

World Health Organization (WHO) (2020b) 'Novel Coronavirus (2019-nCoV)', WHO Bulletin.

World Health Organization (WHO) (2020c) 'Rational use of personal protective equipment for coronavirus disease 2019 ( COVID-19 )', Who. 